GDVERNANCE: Jurnal IImiah Kajian Politik Lokal dan Pembangunan

ISSN: 2406-8721 (Media Cetak) dan ISSN: 2406-8985 (Media Online)

Volume 7 Nomor 4 Juni 2021

\title{
STRATEGI LEMBAGA ADAT MELAYU DUSUN MUARA KUAMANG DALAM PENYELESAIAN KONFLIK LAHAN
}

\author{
Ridwan $^{1}$, Yuli Nopriyani ${ }^{2}$ \\ Program Studi Ilmu Pemerintahan, Fakultas Ilmu Sosial dan Ilmu Politik. \\ Universitas Muara Bungo. Jalan. Diponegoro 27 Muara Bungo, Provinsi Jambi. \\ Email: iwan09ukm@gmail.com
}

\begin{abstract}
In the social life of indigenous Malay community has an important role, both as a basis for the action, as well as how to solve the problems. Lembaga Adat Melayu Dusun Muara Kuamang has been actively involved in land conflicts in Hamlet menyelsasikan Kuamang Estuary. This study examines the strategies of the Institute of Traditional Malay village in Muara Kuamang menyelelesaikan land conflicts in Dusun Muara Kuamang. This research was conducted in Muara Kuamang Hamlet with the research period January to April 2020. The results of the study found that customary law can be used as an alternative to conflict resolution that is more knowledgeable and prudent. Customary law is able to provide a major role in resolving land conflicts that occur in the hamlet of Muara Kuamang. Strategy Board Raya Dusun Muara Kuamang in land conflict resolution in Dusun Muara Kuamang including through mediation and custom assembly. The constraints Lembaga Adat Melayu Dusun Muara Kuamang. in the settlement of the land conflict in Dusun Muara Kuamang, that is, the disputing parties did not comply, the limitations of witnesses in the trial and the order of the trial were not complied with by the disputing parties.
\end{abstract}

Keywords: strategy, customary institutions, conflict, land, obstacles

\begin{abstract}
ABSTRAK
Dalam kehidupan sosial masyarakat melayu adat memiliki peran penting, baik itu sebagai landasan dalam bertindak, maupun sebagai cara dalam menyelesaikan permasalahan. Lembaga Adat Melayu Dusun Muara Kuamang telah berperan aktif dalam menyelsasikan konflik lahan di Dusun Muara Kuamang. Penelitian ini mengkaji strategi Lembaga Adat Melayu Dusun Muara Kuamang dalam menyelelesaikan konflik lahan di Dusun Muara Kuamang. Penelitian ini dilaksanakan di Dusun Muara Kuamang dengan waktu penelitian Januari hingga April 2020. Hasil kajian mendapati bahwa hukum adat dapat digunakan sebagai alternatif penyelesaian konflik yang bersifat lebih arif dan bijaksana. Hukum adat mampu memberikan peran yang besar dalam penyelesaian konflik lahan yang terjadi di Dusun Muara Kuamang. Strategi Lembaga Adat Melayu Dusun Muara Kuamang dalam penyelesaian konflik lahan di Dusun Muara Kuamang diantaranya melalui mediasi dan sidang adat. Adapun kendala Lembaga Adat Melayu Dusun Muara Kuamang. dalam penyelesaian konflik lahan di Dusun Muara Kuamang yakni pihak yang bersengketa tidak patuh, keterbatasan saksi di persidangan dan tertib persidangan tidak dipatuhi oleh pihak yang bersengketa.
\end{abstract}

Kata kunci: strategi, lembaga adat, konflik, lahan, hambatan.

\section{PENDAHULUAN}

Adat bersendi syara', syara' barsendi kitabullah, peribahasa tersebut menggambarkan tentang eratnya hubungan antara adat istiadat dengan agama dalam filosopi hidup masyarakat Kabupaten Bungo. dalam peribahasa di atas dijelaskan bahwa adat istiadat berlandaskan agama, dan agama berlandaskan Al-Qur'an. Dalam pepatah adat Bungo lain di sebutkan "Adat ditangan Ninik Mamak, Undang ditangan Rajo (Pemerintah)" ${ }^{1}$ dalam kehidupan sosial masyarakat Kabupaten Bungo memiliki dua unsur hukum yang secara bersamaan harus dipatuhi oleh masyarakat bungo, yaitu hukum adat dan hukum positif.

\footnotetext{
${ }^{1}$ H. MAHMUD As, "Pedoman Adat Bungo", Lembaga Adat Kabupaten Bungo 2004 hlm.01 


\section{GDVERNANCE: Jurnal IImiah Kajian Politik Lokal dan Pembangunan \\ ISSN: 2406-8721 (Media Cetak) dan ISSN: 2406-8985 (Media Online) \\ Volume 7 Nomor 4 Juni 2021}

Hukum adat dijalankan oleh Ninik Mamak sebagai tokoh yang diberi amanat untuk menjalankannya, sedangkan hukum positif berada dibawah kekuasaan pemerintah. "Adat selengkung negeri, undang selengkung alam," artinya dalam kehidupan masyarakat melayu termasuk masyarakat Kabupaten Bungo, tentunya berada dalam kerangka hukum adat dan hukum positif. ${ }^{2}$ Pepatah adat diatas memperlihatkan jalinan yang erat antara adat, agama dan aturan Pemerintah dalam kehidupan masyarakat Kabupaten Bungo. Demikian pula antara pimpinan adat, ulama dan Pemerintah dalam sistem Pemerintahan Dusun digambarkan dalam pepatah Tali nan bepintal tigo yaitu: pejabat pemerintahan dusun, pemangku adat, pegawai syarak. ${ }^{3}$

Dari pandangan diatas dapat diketahui bahwa adat istiadat merupakan sistem nilai yang tidak dapat dipisahkan dari setiap sisi kehidupan masyarakat Kabupaten Bungo. Adat istiadat merupakan elemen perekat dalam sendi kehidupan masyarakat Kabupaten Bungo yang memungkinkan masyarakat tumbuh dan berkembang dalam suasana kekeluargaan yang aman dan damai, selain itu adat istiadat juga merupakan potensi budaya yang sangat tinggi nilainya, keberadaan adat istiadat banyak mengandung falsafah dan nilai-nilai yang dapat menjadi pedoman hidup dan sekaligus menjadi jawaban bagi masalah sosial yang timbul dimasyarakat. Adat istiadat juga disandingkan dengan hukum positif, sebagai alternatif penyesaian sengketa, konflik, maupun permasalahan sosial lainnya yang sering kali terjadi di Kabupaten Bungo. Lemahnya pengamalan terhadap nilai-nilai adat istiadat berdampak pada semakin tingginya sifat individualisme dimasyarakat, semakin hari tingkat kenakalan remaja semakin tinggi, angka kriminalitas terus bertambah, bahkan gesekan sosial kerap terjadi dimasyarakat. Untuk itu, perlunya menanamkan nilai-nilai sosial ditengah masyarakat terutama nilai-nilai yang bersumber dari adat-istiadat.

Dalam kehidupan sosial masyarakat melayu adat memiliki peran penting, baik itu sebagai landasan dalam bertindak, maupun sebagai cara dalam menyelesaikan permasalahan. Dalam penelitian ini, penulis akan melihat dari perspektif adat sebagai sarana penyelesaian konflik lahan. Ada beberapa kasus konflik lahan yang terjadi di tengah masyarakat Dusun Muara Kuamang yang jumlahnya dari tahun ketahun relatif tinggi, antara lain sebagai berikut:

Tabel 1: Kasus Konflik Lahan Dusun Muara Kuamang Dalam Lima Tahun Terakhir

\begin{tabular}{|c|c|c|l|l|}
\hline No & Tahun & Jml Kasus & Jenis sengketa & \multicolumn{1}{|c|}{ Keterangan } \\
\hline 1 & 2016 & 8 & Perkebunan & Semua kasus selesai \\
2 & 2017 & 7 & Perkebunan & Semua kasus selesai \\
3 & 2018 & 8 & Perkebunan & Semua kasus selesai \\
4 & 2019 & 9 & Perkebunan & 7 kasus selesai, 2 belum \\
5 & 2020 & 3 & Perkebunan & 2 kasus 2019, 1 kasus baru \\
\hline
\end{tabular}

Sumber: Kantor Dusun Muara Kuamang, 2019

\section{METODE}

Metode merupakan cara yang digunakan untuk mencapai suatu tujuan dengan menggunakan langkah-langkah dan tehknik tertentu. Metode atau metodologi berasal dari bahasa yunani "methodos" yang berarti cara atau jalan. ${ }^{4}$ Dalam penelitian ini penulis menggunakan metode kualitatif dengan desain deskriptif, yaitu penelitian yang memberi gambaran secara cermat mengenai individu atau kelompok tertentu tentang keadaan dan gejala yang terjadi. Penelitian deskriptif adalah merupakan penelitian terhadap status, sikap, pendapat kelompok individu, perangkat kondisi dan prosedur suatu sistem pemikiran atau peristiwa dalam rangka membuat deskripsi atau gambaran

\footnotetext{
2 Ibid hlm.01

${ }^{3}$ H. MAHMUD As (Ketua Lembaga Adat Melayu Kabupaten Bungo), Adat Dalam Kabupaten Bungo, (http://andragbfm.blogspot.com/2010/09/adat-kabupaten-bungo.html) 21/01/2020-10.30

${ }^{4}$ Ulber Silalahi, "Metode Penelitian Sosial”, Bandung: Refika Aditama 2009 hlm 12
}

Penerbit:

LKISPOL (Lembaga Kajian Ilmu Sosial dan Politik)

redaksigovernance@gmail.com//admin@1kispol.or.id
Indexed:

GOOgle PKP|INDEX 0 onesearch




\section{GDVERNANCE: Jurnal IImiah Kajian Politik Lokal dan Pembangunan \\ ISSN: 2406-8721 (Media Cetak) dan ISSN: 2406-8985 (Media Online) \\ Volume 7 Nomor 4 Juni 2021}

secara sistematik dan analitik yang dapat digunakan untuk memecahkan suatu masalah actual pada masa kini. ${ }^{5}$

Penelitian ini akan dilaksanakan di lingkungan Lembaga Adat Melayu Dusun Muara Kuamang. Penentuan lokasi penelitian ini dipilih secara sengaja karena, Lembaga Adat Melayu Dusun Muara Kuamang merupakan salah satu bagian dari Lembaga Adat Melayu Kabupaten Bungo yang merupakan struktur paling dasar dalam kelembagaan Lembaga Adat Melayu Kabupaten Bungo yang bersentuhan langsung dengan permasalahan sosial yang terjadi ditengah masyarakat Dusun Muara Kuamang. Pemilihan lokasi penelitian ini juga didasari oleh banyaknya konflik yang terjadi masyarakat yang terjadi di Dusun Muara Kuamang, seperti konflik pertanahan, ketenaga kerjaan, Konflik sosial, hingga kenakalan remaja. Dari sekian banyak konflik yang terjadi di Dusun Muara Kuamang, lembaga adat selalu meliliki peran penting dalam penyelesaian konflik, mulai dari mediasi hingga pada tahap putusan dan sangsi yang diberikan. Penelitian ini dilaksanakan pada bulan Januari hingga April Tahun 2020.

Teknik pengumpulan data merupakan cara yang digunakan peneliti untuk mendapatkan data dalam suatu penelitian. Pada penelitian kali ini peneliti memilih jenis penelitian kualitatif, data kwalitatif merupakan sumber dari deskripsi yang luas dan berlandasan kukuh, serta memuat penjelasan tentang proses-proses yang terjadi dalam lingkup setempat. Dengan data kwalitatif kita dapat mengikuti dan memahami alur peristiwa secara kronologis, menilai sebab akibat dalam lingkup pikiran orang-orang setempat dan memperoleh penjelasan yang banyak dan bermanfaat. ${ }^{6}$ Data yang diperoleh haruslah mendalam, jelas dan spesifik, Selanjutnya dijelaskan oleh Sugiyono bahwa pengumpulan data dapat diperoleh dari hasil observasi, wawancara, dokumentasi, dan gabungan/triangulasi. Pada penelitian ini peneliti menggunakan teknik pengumpulan data dengan cara observasi, dokumentasi, dan wawancara.

Dalam pemilihan informan penulis menggunakan metode purposive sampling yaitu pemilihan subyek yang ada dalam posisi terbaik untuk memberikan informasi yang dibutuhkan. ${ }^{7}$ Yang menjadi informan dalam penelitian ini adalah pihak-pihak yang berada dilingkungan Lembaga Adat Melayu Kabupaten Bungo. berikut adalah tabel informan yang akan menjadi narasumber dalam penelitian ini.

Tabel 2: Informan Penelitian

\begin{tabular}{|l|l|l|c|}
\hline No & Nama & Jabatan & Jumlah \\
\hline 1 & H.Machmud.HS & Ketua LAM Kab. Bungo & 1 \\
\hline 2 & Sobirin & $\begin{array}{l}\text { Pemangku Adat Dusun Muara } \\
\text { Kuamang }\end{array}$ & 1 \\
\hline 3 & A.Roni & Ketua LAM Dusun Muara Kuamang & 1 \\
\hline 4 & M.amin & Anggota LAM Dusun Muara Kuamang & 1 \\
\hline 5 & Andi Sopian & Ketua BPD Dusun Muara Kuamang & 1 \\
\hline 6 & M.Safi'i & Sekdus Muara Kuamang & 1 \\
\hline 7 & Abas Hamzah & Tokoh Masyarakat & 1 \\
\hline Total & & & 7 \\
\hline
\end{tabular}

\footnotetext{
${ }^{5}$ Suprapto, "Metodologi Penelitian Ilmu Pendidikan dan Ilmu Pengetahuan Sosial”, 2013 Hlm 13

${ }^{6}$ Ulber Silalahi, "Metode Penelitian Sosial” Bandung: Refika Aditama, 2009 hlm 284

${ }^{7}$ Ulber Silalahi, "Metode Penelitian Sosial” Bandung: Refika Aditama, 2009 hlm 272
}

Penerbit:

LKISPOL (Lembaga Kajian Ilmu Sosial dan Politik) redaksigovernance@gmail.com//admin@1kispol.or.id
Indexed: 


\section{GDVERNANCE: Jurnal IImiah Kajian Politik Lokal dan Pembangunan \\ ISSN: 2406-8721 (Media Cetak) dan ISSN: 2406-8985 (Media Online) \\ Volume 7 Nomor 4 Juni 2021}

PEMBAHASAN

\section{Strategi Lembaga Adat Melayu Dusun Muara Kuamang Dalam Penyelesaian Konflik Lahan.}

\section{Mediasi}

Mediasi yang dijalankan tokoh-tokoh adat memiliki kekuatan dalam penyelesaian sengketa, baik dalam sengketa ranah privat maupun ranah publik. Mediasi sebagai bentuk penyelesaian sengketa telah dipraktekan oleh masyarakat sebagai warisan kebudayaan. Warisan ini dipertahankan secara turun temurun, karena nilai filosofi mediasi mengembalikan fungsi manusia sebagai mahluk sosial. Konflik atau sengketa telah mengganggu ketenteraman masyarakat sebagai mahluk sosial. Mediasi menjadikan para pihak yang bersengketa dapat bersatu kembali, hidup rukun, dan memperkuat kembali tali kekerabatan setelah terjadinya konflik dan sengketa lahan. Keinginan menyelesaikan sengketa, bukan hanya menjadi kewajiban pemangku adat atau tokoh masyarakat, tetapi menjadi kewajiban bagi setiap individu masyarakat.

Menurut Ketua Lembaga Adat Melayu Dusun Muara Kuamang, A Roni:

"Mediasi memiliki peran penting dalam proses penyelesaian sengketa lahan di Dusun Muara Kuamang, dan merupakan kekuatan besar bagi Lembaga Adat Dusun dalam menyelesaikan sengketa lahan".

Selanjutnya Sobirin (Rio/pemangku adat Dusun Muara Kuamang) mengatakan:

"Dalam mediasi, keputusan yang dihasilkan sangat kuat, karena keputusan yang diambil merupakan kesepakatan dari kedua belah pihak yang bersengketa, tentu tidak ada yang merasa dirugikan atas keputusan kedua belah pihak". ${ }^{9}$

Secara sosial, mediasi dalam hukum adat memiliki kekuatan yang besar untuk mengikat hubungan sosial yang ada antara kedua pihak yang bersengketa. Karena, kesepakatan yang dihasilkan merupakan itikat baik dari kedua belah pihak untuk menyelesaikan sengketa lahan secara kekeluargaan. Dalam penelitian ini, berdasarkan hasil wawancara dengan beberapa narasumber dapat dipastikan bahwa proses mediasi lebih mengutamakan kebijaksanaan dan memiliki peran yang besar dalam menjaga hubungan sosial antara pihak yang bersengketa. Menurut pendapat H.Abas Hamzah (Tokoh Masyarakat) peran Lembaga Adat Dusun sebaga mediator dalam konflik lahan.

"Salah satu bentuk peranan lembaga adat Dusun Muara Kuamang dalam penyelesaian konflik lahan yaitu dengan menjadi mediator dalam proses mediasi antara pihak yang bersengketa. Mediasi merupakan bentuk awal dalam penyelesaian konflik lahan, namun jika mediasi tidak dapat dilaksanakan atau tidak menyelesaikan sengketa antara pihak yang bersengketa maka pihak Lembaga Adat Melayu Dusun akan melakukan langkah selanjutnya, yaitu membawa sengketa lahan ke sidang adat". ${ }^{10}$

Selanjutnya Sobirin (Rio/pemangku adat Dusun Muara Kuamang) mengatakan:

"Dalam proses mediasi kesulitan terjadi ketika kita harus mencari titik temu antara kedua belah pihak yang bersengketa. Karena banyak terjadi, mereka selalu memaksakan kehendak dan tidak perduli dengan pertimbangan-pertimbangan yang

\footnotetext{
${ }^{8}$ Hasil Wawancara dengan Ketua lembaga Adat Melayu Dusun Muara Kuamang Pada tanggal 15 Februari 2020 Pukul 20:30 Wib

${ }^{9}$ Hasil Wawancara dengan Rio/Pemangku Adat Dusun Muara Kuamang Pada tanggal 14 Februari 2020 Pukul 13:05 Wib

${ }^{10}$ Hasil Wawancara dengan tokoh masyarakat Dusun Muara Kuamang Pada tanggal 15 Februari 2020 Pukul 16:00 Wib
}

Indexed: 


\section{GDVERNANCE: Jurnal Ilmiah Kajian Politik Lokal dan Pembangunan \\ ISSN: 2406-8721 (Media Cetak) dan ISSN: 2406-8985 (Media Online) \\ Volume 7 Nomor 4 Juni 2021}

ada. Jika tidak ditemukan kesepakatan, maka kasus sengketa lahan yang terjadi akan dibawa ke proses sidang adat". ${ }^{11}$

Pelaksanaan hasil mediasi adalah tanggung jawab dan kewajiban para pihak yang telah membuat kesepakatan. Kewajiban melaksanakan hasil mediasi atas dasar kesadaran masing-masing pihak untuk menyelesaikan sengketa mereka, dan bukan atas dasar dari satu pihak, apalagi paksaan dari pihak lain. Adanya kesepakatan (agreement) tertulis yang mengakhiri sengketa para pihak menjadi sangat penting bagi pelaksanaan mediasi. Hal ini bukan, berarti bahwa tanpa adanya pernyataan tertulis, membuat hasil mediasi tidak dapat dilaksanakan di lapangan. Masyarakat hukum adat yang cendrung tidak menuangkan kesepakatan bersama dalam bentuk tertulis, dalam kenyataan cukup barhasil dilaksanakan oleh para pihak yang bersengketa.

Pelaksanaan hasil mediasi dalam praktiknya, bukan hanya semata-mata menjadi tanggung jawab para pihak yang bersengketa, tetapi juga terlibat para tokoh adat yang telah bertindak sebagai mediator. Pada sisi lain keluarga besar para pihak yang bersengketa, dapat juga menjadi pendorong bagi memudahkan realisasi kesepakatan mediasi. Oleh karena itu, kontrol masyarakat menjadi amat penting dalam pelaksanaan hasil mediasi. Hal ini juga mengingatkan kembali bahwa masyarakat dapat melakukan intervensi, jika hasil mediasi tidak dilaksanakan dengan baik.

Menurut Ketua Lembaga Adat Melayu Dusun Muara Kuamang, A Roni:

"Dalam upaya penyelesaian sengketa lahan, maka kita sebagai Lembaga Adat Dusun selalu mendahulukan mediasi sebagai langkah awal dalam penyelesaian konflik lahan. Langkah mediasi kita ambil, agar tidak terjadi kegaduhan dan agar permasalahan sengketa lahan dapat diselesaikan secara kekeluargaan dan tanpa harus ada yang merasa dirugikan. Untuk pelaksanaan hasil putusan mediasi tetap dikawal oleh pihak lembaga adat". ${ }^{12}$

Pendapat yang sama juga diungkapkan oleh H.Abas Hamzah (Tokoh Masyarakat) yaitu:

"Salah satu bentuk peranan lembaga adat Dusun Muara Kuamang dalam penyelesaian konflik lahan yaitu dengan menjadi mediator dalam proses mediasi antara pihak yang bersengketa sampai seluruh putusan mediasi dibuat dan dijalankan oleh kedua pihak. Mediasi merupakan bentuk awal dalam penyelesaian konflik lahan, namun jika mediasi tidak dapat dilaksanakan atau tidak menyelesaikan sengketa antara pihak yang bersengketa maka pihak Lembaga Adat Melayu Dusun akan melakukan langkah selanjutnya, yaitu membawa sengketa lahan ke sidang adat". ${ }^{13}$

Selanjutnya Sobirin (Rio/pemangku adat Dusun Muara Kuamang) mengatakan:

"Putusan mediasi dibuat secara tertulis, ditandatangani oleh kedua pihak serta saksi-saksi dan putusan hasil mediasi harus dijalankan oleh kedua belah pihak. Kalau bisa dilakukan mediasi, maka kita lakukan mediasi, namun jika dalam mediasi tidak juga dapat menyelesaikan sengketa, maka kita lakukan sidang adat, dan keputusan sidang adat bersifat mengikat". ${ }^{14}$

Berdasarkan beberapa hasil wawancara diatas maka dapat penulis simpulkan, bahwa mediasi merupakan salah satu cara yang dilakukan oleh lembaga Adat Melayu Dusun Muara Kuamang dalam

\footnotetext{
${ }^{11}$ Hasil Wawancara dengan Rio/Pemangku Adat Dusun Muara Kuamang Pada tanggal 14 Februari 2020 Pukul 13:05 Wib

${ }^{12}$ Hasil Wawancara dengan Ketua lembaga Adat Melayu Dusun Muara Kuamang Pada tanggal 15 Februari 2020 Pukul 20:30 Wib

${ }^{13}$ Hasil Wawancara dengan tokoh masyarakat Dusun Muara Kuamang Pada tanggal 15 Februari 2020 Pukul 16:00 Wib

${ }^{14}$ Hasil Wawancara dengan Rio/Pemangku Adat Dusun Muara Kuamang Pada tanggal 14 Februari 2020 Pukul 13:05 Wib
}

Indexed: 


\section{GDVERNANCE: Jurnal IImiah Kajian Politik Lokal dan Pembangunan \\ ISSN: 2406-8721 (Media Cetak) dan ISSN: 2406-8985 (Media Online) \\ Volume 7 Nomor 4 Juni 2021}

penyelesaian konflik lahan. Pihak Lembaga Adat Melayu Dusun Muara Kuamang akan membantu sepenuhnya proses mediasi hingga dihasilkannya kesepakatan dalam mediasi tersebut, dan pengawalan terhadap pelaksanaan putusan mediasi. Mediasi merupakan suatu tindakan yang lebih mengedepankan nilai-nilai kearifan dan kebijaksanaan serta kekeluargaan.

\section{Sidang Adat}

Sidang adat merupakan upaya terakhir yang dilakukan dalam penyelesaian konflik lahan. Sidang dilakukan dengan beberapa tahapan, mulai dari pendaftaran sidang, penjadwalan sidang, pengecekan kondisi fisik lahan, mendengarkan saksi-saksi yang dihadirkan, hingga sampai keputusan sidang dan hasil sidang bersifat mengikat.

Seperti dijelaskan oleh Sobirin (Rio/pemangku adat Dusun Muara Kuamang) :

"Dalam proses pelaksanaannya, sidang adat dibagi kedalam tiga tahapan utama yaitu, sidang pertama membacakan pokok perkara, serta mendengarkan kesaksian dari kedua belah pihak dan memperlihatkan bukti-bukti yang ada. Sidang kedua dilakukan pemeriksaan terhadap kondisi lahan yang menjadi sengketa bersama dengan seluruh unsur peserta sidang dan kedua pihak yang bersengketa. Sidang ketiga dengan agenda membacakan keterangan yang didapat dari sidang pertama dan sidang kedua, bukti-bukti yang ditemukan dilapangan, serta mendengarkan keterangan lanjutan. Kemudian seluruh peserta sidang berdiskusi secara terbuka dengan ketentuan pihak yang bersengketa diminta untuk meninggalkan ruang sidang, dan terakhir yaitu pembacaan putusan sidang oleh pimpinan sidang ". ${ }^{15}$

Seperti dijelaskan oleh A.Roni (Ketua LAM Dusun Muara Kuamang) bahwa:

"Tahapan dalam sidang adat untuk menyelesaikan permasalahan tentang sengketa lahan itu dimulai dari Pendaftaran Perkara, Permohonan perkara dibuat secara tertulis oleh yang menggugat dan mengajukan Saksi-saksi, dan untuk saksi paling sedikit dua orang. Pemohon/Penggugat dan termohon menunggu surat panggilan untuk menghadiri persidangan. Dalam hal ini, sidang akan dijadwalkan oleh Lembaga Adat Melayu Dusun bersama Pemerintah Dusun". ${ }^{16}$

Teknis pelaksanaan sidang adat disusun dengan sangat rapi, dan pembagian tugas dilakukan dengan baik demi terlaksananya sidang yang dapat memberikan rasa adil terhadap masyarakat.

Menurut Ketua Lembaga Adat Melayu Dusun Muara Kuamang, A Roni:

"Dalam teknis pelaksanaan sidang adat, ada beberapa tahapan yang kita lalui, pada tahapan pertama dimulai dari sidang pertama yakni Pimpinan sidang membacakan Permohonan/Gugatan, kemudian dilanjutkan dengan Mendengarkan keterangan Pemohon/termohon dan saksi-saksi. Selanjutnya akan dilakukan pengecekan lokasi sengketa yang menjadi pokok perkara, dalam hal ini biasanya dipimpin langsung oleh Rio. Pada saat turun kelapangan Pemohon dan termohon tidak boleh membawa senjata tajam atau barang yang membahayakan keselamatan, hal tersebut dilakukan guna menghindari kejadian yang tidak diinginkan, jika terjadi keributan dalam penentuan batas lahan yang menjadi sengketa. Selanjutnya sidang kedua akan dilakukan pembacaan hasil temuan yang didapat dari lokasi perkara oleh pimpinan sidang, serta meminta keterangan tambahan kepada Pemohon, termohon danSaksisaksi bila dianggap perlu. Namun dalam hal ini, Pimpinan sidang berhak mengajukan Saksi bila dianggap perlu. Terakhir adalah sidang ketiga, yang merupakan sidang penutup Pada sidang ini pimpinan sidang akan mengambil

\footnotetext{
${ }^{15}$ Hasil Wawancara dengan Rio/Pemangku Adat Dusun Muara Kuamang Pada tanggal 14 Februari 2020 Pukul 13:05 Wib

${ }^{16}$ Hasil Wawancara dengan Ketua LAM Dusun Muara Kuamang Pada tanggal 15 Februari 2020 Pukul 20:30 Wib
}

Indexed: 
ISSN: 2406-8721 (Media Cetak) dan ISSN: 2406-8985 (Media Online)

Volume 7 Nomor 4 Juni 2021

keputusan. Maka dalam mengambil keputusan, Pemohon dan termohon akan dipersilahkan meninggalkan ruang sidang. Pimpinan sidang akan mendengarkan pendapat dan saran dari seluruh anggota sidang dan musyawarah pimpinan sidang dalam mengambil Keputusan. Dalam hal ini, anggota Musyawarah ditentukan oleh anggota sidang, anggota musyawarah biasanya berjumlah ganjil, 5, 7, 9 dan seterusnya, hal tersebut dilakukan agar lebih mudah dalam mengambil keputusan akhir. Selanjutnya dalam pembacaan putusan hasil sidang oleh pimpinan sidang atau juru bicara musyawarah. Setelah perkara diputuskan, pihak yang tidak puas atas putusan tersebut dapat mengajukan banding, Selambat-lambatnya empat belas hari sejak hasil putusan perkara ditetapkan. Namun apabila sampai pada waktu yang ditetapkan tidak ada upaya hukum dari pihak yang bersengketa, maka secara otomatis akan dianggap menyetujui hasil putusan sidang dan Putusan sidang tetap berlaku dan akan dilaksanakan eksekusi terhadap putusan perkara yang dipimpinoleh Rio". ${ }^{17}$

Pernyataan Ketua Lembaga Adat Melayu Dusun Muara Kuamang diatas ditegaskan kembali oleh H.Abas Hamzah (Tokoh Masyarakat sekaligus mantan Rio Dusun Muara Kuamang) yaitu:

"Dalam pelaksanaan sidang konflik lahan, semua proses harus dilaksanakan secara terstruktur dan sistematis, sesuai dengan acuan dan pedoman sidang adat yang sudah ada. Hal tersebut dilakukan agar tidak terjadi kesalahan dan dalam pengambilan keputusan akhir dapat dilakukan dengan baik, dan tidak menciderai rasa keadilan. Untuk teknis pelaksanaan sidang adat sepenuhnya menjadi kewenangan Lembaga Adat beserta Pemerintah Dusun". ${ }^{18}$

Selanjutnya Sobirin (Rio/pemangku adat Dusun Muara Kuamang) menambahkan:

"Dalam penyelesaian sengketa lahan, maka harus dilakukan sesuai dengan urutan atau tahapan penyelesaian yang sudah menjadi acuan selama ini. Seperti yang kita ketahui, perkara sengketa lahan merupakan perkara yang sensitif sehingga murah menyulut emosi pihak yang bersengketa, maka dalam penyelesaiannyapun perlu kehati-hatian agar terciptanya rasa keadilan dan tidak menimbulkan masalah baru dari hasil putusan sidang, serta dapat diterima oleh semua pihak". ${ }^{19}$

Dalam menjaga kelancaran dan kondusifitas proses persidangan, maka dibuatlah tata tertib sidang, hal ini sangat diperlukan untuk membatasi agar tidak terjadi hal-hal yang tidak diinginkan. Seperti yang disampaikan oleh Andi Sopian (Ketua Badan Permusyawaratan Dusun Muara Kuamang) yaitu:

"Kita menjalankan sidang harus dengan tata tertib, agar tidak timbul kegaduhan karena sidang yang tidak terstruktur. Hal ini berfungsi untuk menghindari terjadinya keributan selama berlangsungnya proses persidangan". ${ }^{20}$

M.Safi'i (Sekretaris Dusun Muara Kuamang) menjelaskan:

"Dalam menjalani persidangan tata tertib sidang merupakan pedoman bagi seluruh peserta sidang dalam bersikap dan bertindak agar dapat dilaksanakan. Adapun tata tertib sidang yang selama ini kita gunakan seperti: Seluruh anggota sidang,

\footnotetext{
${ }^{17}$ Hasil Wawancara dengan Ketua lembaga Adat Melayu Dusun Muara Kuamang Pada tanggal 15 Februari 2020 Pukul 20:30 Wib

${ }^{18}$ Hasil Wawancara dengan tokoh masyarakat Dusun Muara Kuamang Pada tanggal 15 Februari 2020 Pukul 16:00 Wib

${ }^{19}$ Hasil Wawancara dengan Rio/Pemangku Adat Dusun Muara Kuamang Pada tanggal 14 Februari 2020 Pukul 13:05 Wib

${ }^{20}$ Hasil Wawancara dengan Ketua BPD Dusun Muara Kuamang Pada tanggal 16 Februari 2020 Pukul 14:10 Wib
}

Indexed: 
pemohon dan termohon harus menandatangani daftar hadir. Selanjutnya, selama masa persidangan berlangsung anggota sidang, Pemohon dan termohon harus duduk dengan sopan dan tertib ditempatnya masing-masing dan memelihara ketertiban dalam ruang sidang Sidang. Sidang akan dimulai pada pukul 20.00 WIB sampai dengan pukul 24.00, sidang dilakukan pada malam hari dimaksudkan agar tidak mengganggu aktivitas keseharian masyarakat. Kemudian sidang berikutnya dijadwalkan melalui musyawarah Anggota sidang, pemohon dan termohon tidak boleh memotong pembicaraan disaat yang lain memberikan keterangan Dalam ruang sidang, siapapun wajib menunjukkan sikap hormat kepada pimpinan sidang. Dan siapapun dilarang membawa senjata api, senjata tajam dan benda yang dapat membahayakan keamanan Pada waktu sidang berlangsung. Peserta sidang dilarang mengaktifkan Hand Phone, karena takut dapat mengganggu jalannya persidangan, dan dilarang merekam dan mengambil gambar tanpa seizin pimpinan sidang". ${ }^{21}$

Selanjutnya Sobirin (Rio/pemangku adat Dusun Muara Kuamang) mengatakan:

"Tata tertib sidang merupakan hal yang sangat penting demi lancarnya proses persidangan. Jika tata tertib tidak dipatuhi, maka dapat dipastikan proses persidangan akan terganggu dan hasil persidanganpun tidak akan dapat diterima dengan baik, serta dapat memicu timbulnya perselisihan antara kedua belah pihak yang bersengketa". 22

Sidang adat merupakan salah satu tindakan yang diambil oleh Lembaga Adat Melayu Dusun Muara Kuamang bersama Pemerintah Dusun Muara Kuamang dalam penyelesaian konflik lahan yang terjadi di Dusun Muara Kuamang, jika proses mediasi tidak membuahkan hasil. Sidang adat yang dilakukan secara terbuka dan transparan serta melalui proses yang sistematis akan mampu menyelesaikan konflik lahan yang terjadi.

\section{Kendala yang dihadapi oleh Lembaga Adat Melayu Dusun Muara Kuamang dalam penyelesaian konflik lahan. \\ Pihak Yang Bersengketa Tidak Patuh}

Dalam wawancara dengan narasumber, penulis mendapatkan informasi tentang seberapa besar kendala yang dihadapi oleh Lembaga Adat Melayu Dusun Muara Kuamang dalam menyelesaikan sengketa lahan. Kendala yang paling mendasar yaitu tentang ketidakpatuhan pihak-pihak yang bersengketa terhadap Proses Persidangan. Dijelaskan oleh Andi Sopian (Ketua Badan Permusyawaratan Dusun Muara Kuamang) yaitu:

"Banyak hal tak terduga bisa terjadi dalam sidang, namun kendala yang sering dihadapi yakni ketidak patuhan pihak yang bersengketa terhadap tata tertib sidang. Tindakan ini berdampak sangat besar terhadap proses persidangan, dan dapat memancing keributan. Kendala lain juga ada, seperti tidak adanya bukti surat kepemilikan tanah, sulitnya mencari saksi, karena kebanyakan masyarakat merasa keberatan untuk menjadi saksi dan tidak mau dikaitkan dengan sengketa yang ada". ${ }^{23}$

Kemudian dijelaskan juga oleh M.Safi'i (Sekretaris Dusun Muara Kuamang) bahwa:

"Hampir disetiap sidang yang kita lakukan, kendala yang kita temui relatif sama, yaitu ketidakpatuhan pihak yang bersengketa terhadap tata tertib sidang, meskipun setiap sebelum memulai persidangan tata tertib selalu dibacakan. Perihal

\footnotetext{
${ }^{21}$ Hasil Wawancara dengan Sekretaris Dusun Muara Kuamang Pada tanggal 15 Februari 2020 Pukul 14:30 Wib

${ }^{22}$ Hasil Wawancara dengan Rio/Pemangku Adat Dusun Muara Kuamang Pada tanggal 14 Februari 2020 Pukul 13:05 Wib

${ }^{23}$ Hasil Wawancara dengan Ketua BPD Dusun Muara Kuamang Pada tanggal 16 Februari 2020 Pukul 14:10 Wib
}

Indexed: 


\section{GDVERNANCE: Jurnal Ilmiah Kajian Politik Lokal dan Pembangunan \\ ISSN: 2406-8721 (Media Cetak) dan ISSN: 2406-8985 (Media Online) \\ Volume 7 Nomor 4 Juni 2021}

ini terjadi karena kurangnya kesadaran pihak yang bersengketa untuk menjalankan tata tertib persidangan dan juga disebabkan oleh kedua belah pihak yang merasa paling benar, hingga seakan-akan memaksakan kehendak dan mereka tidak perduli dengan bukti-bukti dan saksi-saksi yang dihadirkan dalam persidangan". ${ }^{24}$

Pemahaman masyarakat terhadap tata tertib sidang perlu dibangun, agar uapaya penyelesaian sengketa lahan melalui proses sidang adat dapat berjalan dengan tertib dan lancar, serta dapat menghasilkan suatu keputusan yang kuat.

\section{Keterbatasan saksi}

Keterbatasan saksi juga menjadi kendala dalam upaya penyelesaian konflik lahan, dalam hal ini tidak banyak pihak yang mau dilibatkan sebagai saksi, karena mereka tidak ingin hal ini menyebabkan timbul perselisihan dengan salah satu pihak yang bersengketa. M.Safi'i (Sekretaris Dusun Muara Kuamang) mengatakan bahwa:

"Kendala lain yang sering kita temui yaitu keterbatasan saksi dan keterangan saksi yang berubah-ubah sehingga kadang kala membuat jengkel peserta sidang, sehingga kesaksian seperti itu tidak dapat dijadikan bahan kajian dalam mengambil keputusan". ${ }^{25}$

Menurut H.Abas Hamzah (Tokoh Masyarakat) yaitu:

"Salah satu yang menjadi kendala dalam menyelesaikan sengketa lahan yaitu sulit mencari orang yang mau bersaksi, karena orang-orang tidak mau dilibatkan dalam suatu perkara". ${ }^{26}$

Salah satu kendala yang dihadapi dalam upaya penyelesaian konflik lahan di Dusun Muara Kuamang, yaitu sulitnya mendapatkan saksi yang kredibel, dan kebanyakan masyarakat tidak mau dilibatkan dalam permasalahan yang terjadi . Jika ada saksi yang dihadirkan oleh pihak yang bersengketa, pada umumnya merupakan keluardga dari pihak-pihak yang bersengketa itu sendiri, dan sudah bisa dipastikan dalam keterangan yang mereka berikan akan cenderung membela pihak yang mereka dukung.

\section{Tertib Persidangan Tidak Dipatuhi}

Sobirin (Rio/pemangku adat Dusun Muara Kuamang) mengatakan:

"Tata tertib sidang merupakan hal yang sangat penting demi lancarnya proses persidangan. Jika tata tertib tidak dipatuhi, maka dapat dipastikan proses persidangan akan terganggu dan hasil persidanganpun tidak akan dapat diterima dengan baik, serta dapat memicu timbulnya perselisihan antara kedua belah pihak yang bersengketa. Selain itu kendala lain juga ada, seperti sulitnya mengumpulkan peserta sidang karena alasan kesibukan masing-masing. Adapula kesulitan lain seperti sidang yang dimulai pada pukul 21.00 sehingga sidangpun harus berakhir larut malam". ${ }^{27}$

Menurut Ketua Lembaga Adat Melayu Dusun Muara Kuamang, A Roni:

"Permasalahan terbesar yang menjadi kendala bagi kita dalam melaksanakan persidangan yaitu berkaitan dengan sumber daya manusia, semua pihak merasa paling benar. Maka dari itu pimpinan sidang harus tegas dalam menyikapi kondisi

\footnotetext{
${ }^{24}$ Hasil Wawancara dengan Sekretaris Dusun Muara Kuamang Pada tanggal 15 Februari 2020 Pukul 14:30 Wib

${ }^{25}$ Hasil Wawancara dengan Sekretaris Dusun Muara Kuamang Pada tanggal 15 Februari 2020 Pukul 14:30 Wib

${ }^{26}$ Hasil Wawancara dengan tokoh masyarakat Dusun Muara Kuamang Pada tanggal 15 Februari 2020 Pukul 16:00 Wib

${ }^{27}$ Hasil Wawancara dengan Rio/Pemangku Adat Dusun Muara Kuamang Pada tanggal 14 Februari 2020 Pukul 13:05 Wib
} 


\section{GDVERNANCE: Jurnal IImiah Kajian Politik Lokal dan Pembangunan \\ ISSN: 2406-8721 (Media Cetak) dan ISSN: 2406-8985 (Media Online) \\ Volume 7 Nomor 4 Juni 2021}

yang terjadi dalam ruang sidang. Jika tidak, sidang akan sulit dikendalikan dan akan terjadi kericuhan. Hal lain yang sering terjadi yaitu lambatnya memulai sidang, karena harus menunggu hadirnya peserta sidang". 28

Pendapat Ketua Lembaga Adat Dusun Muara Kuamang diatas dikuatkan oleh H.Abas Hamzah (Tokoh Masyarakat) yaitu:

"Salah satu kesulitan dalam melaksanakan persidangan yaitu mengendalikan keadaan dalam ruang sidang, jika tidak tepat mengambil keputusan, maka akan dapat menimbulkan kericuhan ". 29

Berdasarkan beberapa pendapat narasumber diatas maka dapat ditarik kesimpulan bahwa kesulitan atau kendala yang dihadapi dalam menyelesaikan sengketa lahan yaitu berkaitan dengan sumber daya manusia dalam memahami tata tertib persidangan, kurangnya alat bukti seperti surat kepemilikan tanah dan kesulitan dalam mencari saksi yang benar-benar memahami kondisi lahan yang menjadi sengketa.

\section{KESIMPULAN}

Hukum adat dapat digunakan sebagai alternatif penyelesaian konflik yang bersifat lebih arif dan bijaksana. Hukum adat mampu memberikan peran yang besar dalam penyelesaian konflik lahan yang terjadi di Dusun Muara Kuamang. Strategi Lembaga Adat Melayu Dusun Muara Kuamang Dalam Penyelesaian Konflik Lahan di Dusun Muara Kuamang Diantaranya melalui mediasi dan siding adat. Adapun kendala Lembaga Adat Melayu Dusun Muara Kuamang. Dalam Penyelesaian Konflik Lahan di Dusun Muara Kuamang yakni pihak yang bersengketa tidak patuh, keterbatasan saksi di persidangan dan tertib persidangan tidak dipatuhi oleh pihak yang bersengketa.

\section{DAFTAR PUSTAKA}

Abbas, Syahrizal. 2009. Mediasi Dalam Perspektif Hukum Syariah, Hukum Adat, Dan Hukum Nasional. Jakarta: Kencana Prenada Media Group.

Bushar, Muhammad. 1995. Pokok-pokok Hukum Adat. Jakarta: Pradnya Pramita.

David Marsh \& Gerry Stoker. 2002. Teori Dan Metode Dalam Ilmu Politik. Bandung: Nusa Media. Gatot Sumartono. 2006. Arbitrase dan Mediasi di Indonesia. Jakarta: PT.Gramedia PustakaUtama. http://andragbfm.blogspot.com/2010/09/adat-kabupaten-bungo.html. Diakses 14 November 2019 pukul $8.10 \mathrm{Wib}$

http://Artikelsiana.blogspot.com/2019/02/pengertian-peran-fungsi-jenis-peran-ciri-syarat-paraahli.html. Diakses 14 November 2019 pukul 8.18 Wib

http://acitya-fisip11.web.unair.ac.id/artikel_detail-74972-ArtikelAN-Pengertian\%20Lembaga.html. Diakses 15 November 2019 pukul 20.15 Wib

http://www.gurupendidikan.co.id/Pengertian Konflik Menurut Para Ahli. Diakses 15 November 2019 pukul $20.25 \mathrm{Wib}$

Lembaga Adat Kabupaten Bungo. 2004 Pedoman Adat Bungo.

Kamus Besar Bahasa Indonesia. 2008. Jakarta: PT.Gramedia Pustaka Utama Silalahi, Ulber. 2009. Metode Penelitian Sosial. Bandung: PT.Refika Aditama .

Suprapto. 2013. Metodologi Penelitian Ilmu Pendidikan dan Ilmu Pengetahuan Sosial Yogyakarta:CAPS

Siagian, Sondang P. 1995. Teori Pengembangan Organisasi. Jakarta: Bumi Aksara.

Soekanto, Soerjono. 1993. Beberapa Teori Sosiologi tentang Struktur Masyarakat. Jakarta: PT. Raja Grafindo Persada.

Undang-Undang Republik Indonesia Nomor 39 Tahun 1999 Tentang Hak Azazi Manusia.Pasal 6.

\footnotetext{
${ }^{28}$ Hasil Wawancara dengan Ketua lembaga Adat Melayu Dusun Muara Kuamang Pada tanggal 15 Februari 2020 Pukul 20:30 Wib

${ }^{29}$ Hasil Wawancara dengan tokoh masyarakat Dusun Muara Kuamang Pada tanggal 15 Februari 2020 Pukul 16:00 Wib
}

Indexed: 